\title{
Hydrologic vulnerability to climate change of the Lerma-Chapala Basin, Mexico
}

\author{
I. Rivas ${ }^{1}$, A. Güitrón ${ }^{1} \&$ M. Montero ${ }^{2}$ \\ ${ }^{I}$ Hydrology Department, Mexican Institute of Water Technology \\ (IMTA), Mexico \\ ${ }^{2}$ National Water Commission, Mexico City (Formerly at IMTA), Mexico
}

\begin{abstract}
The Intergovernmental Panel on Climate Change (IPCC) suggests that vulnerability to climate change depends on three main factors: exposure, sensitivity and adaptive capacity. Each factor was evaluated and an overall methodology was proposed to map hydrologic vulnerability, where adaptation efforts are most needed to sustain environmental conditions. The Lerma-Chapala Basin was used as a case study. This Basin is located in the central part of Mexico and has an extension of $54,450 \mathrm{Km}^{2}$. During the last 40 years, industrial, commercial and agricultural activities have been established to provide supplies to Mexico City located $50 \mathrm{Km}$ east of the basin boundary. Because of such explosive growth, the basin today faces many challenges, for instance water scarcity issues, groundwater depletion and pollution in streams. At the outlet of the basin is the Lake Chapala, the largest water body in Mexico with an average volume of 8 cubic kilometers. Expected climate change effects threaten the environmental sustainability of the basin and a severe reduction in Lake's volume in the future. A downscaling procedure estimated the precipitation from 23 Atmosphere-Ocean General Circulation Models (AOGCMs) by using the Reliability Ensemble Averaging (REA) method. Two climate change scenarios were chosen (A1B and A2) and two time horizons (2030 and 2050). Results showed a decrement in surface runoff up to $21 \%$ (A1B-2050). The modeling results were integrated and mapped using GIS.
\end{abstract}

Keywords: climate change, vulnerability, GIS, water scarcity, AOGCMs, REA, Chapala Lake, adaptation. 


\section{Background}

\subsection{Conceptual framework}

The Mexican Government recognizes that climate change (CC) is the main global environmental challenge of this century and represents one of the greatest threats to the development and overall human well-being. Water resources management decisions depend on historic environmental conditions, for example the water availability in basins. However, climate change incorporates uncertainties in the hydrological cycle that should be considered. Specifically, the rate of change in surface runoff has not been systematically quantified. Then, evaluate the corresponding vulnerability. One objective of the Mexican Government is to further increase the knowledge on water resources vulnerability to climate change [1]. In Mexico, it is well known that the most vulnerable regions are the north and the central parts, being the central part also the most populated. In Mexico, the average per capita water availability per year was $11,500 \mathrm{~m}^{3}$ in $1955 ; 4,900 \mathrm{~m}^{3}$ in 2000 and $3,822 \mathrm{~m}^{3}$ in 2005 . If the precipitation patterns remain constant, only by population growth, Mexico will expect an availability of $3,610 \mathrm{~m}^{3}$ in $2012,3,285 \mathrm{~m}^{3}$ in 2030 and $3,260 \mathrm{~m}^{3}$ in 2050 [2]. In addition, it is projected to have less annual precipitation but with a greater concentration, that is, fewer storms with a higher intensity. Such precipitation regime will decrease annual availability more quickly, especially in arid and semi-arid regions.

\subsection{Climate change scenarios}

In 2001 the Special Report on Emissions Scenarios (SRES) presented future scenarios regarding gas emission greenhouses (GHG) to use in AtmosphereOcean General Circulation Models (AOGCMs) for the development of climate change scenarios [3]. The defined scenarios were also used in the last report of the IPCC [4]. The IPCC will publish its Fifth Assessment Report (AR5) in 2014. The SRES scenarios are grouped in four families of scenarios (A1, A2, B1 and B2) that explore developing alternatives incorporating demographic, economic and technological factors along with resulting GHG emissions. There are no probability levels assigned to any of the SRES scenarios; however it is assumed that the most likely scenarios will be the A1B and A2, thus, these two scenarios and two time horizons were analyzed (2030 and 2050). The year 2009 was considered as the base scenario, which is based on historical conditions. Table 1 shows the analyzed four scenarios.

Table 1: $\quad$ Proposed climate change scenarios.

\begin{tabular}{|c|c|c|}
\hline \multirow{2}{*}{ Time horizons } & \multicolumn{2}{|c|}{ IPCC scenarios } \\
\cline { 2 - 3 } & $\mathrm{A} 1 \mathrm{~B}$ & $\mathrm{~A} 2$ \\
\hline Year 2009 & \multicolumn{2}{|c|}{ Base } \\
\hline Year 2030 & $\mathrm{A}_{1} \mathrm{~B}_{30}$ & $\mathrm{~A} 2_{30}$ \\
\hline Year 2050 & $\mathrm{A}_{3} \mathrm{~B}_{50}$ & $\mathrm{~A} 2_{50}$ \\
\hline
\end{tabular}




\subsection{Estimation of precipitation}

AOGCMs attempt to predict certain climatic parameters in the future, such as carbon dioxide concentration $\left(\mathrm{CO}_{2}\right)$ in the atmosphere, as a result of the different IPCC's scenarios. The results are presented in a spatial and temporal resolution of the climate system (through a grid of points), whose geographical coordinates are evenly distributed (latitude and longitude). SEDEPECC [5] uses a database from 23 AOGCMs and using a reliability ensemble average (REA) method, it was possible to regionalize the models results from precipitation and surface temperature. The REA method quantified the two criteria of bias and convergence for multi-model evaluation, and produced estimates of regional climate change and model reliabilities through a weighted average of the individual AOGCMs results. The results from the two climate change considered scenarios (A1B and A2) are presented on a regular grid of $0.5^{\circ} \times 0.5^{\circ}$ until the end of the 21 st century.

\section{Climate change impacts on surface runoff}

\subsection{Generalities}

Precipitation and temperature changes modify the surface runoff and therefore, the water availability [6]. With a high degree of confidence, it is expected to increase surface runoff between $10 \%$ and $40 \%$ by the middle of the century in higher latitudes due to early snowmelt (in some parts of Canada, for example). It is also estimated an increase in the flooding frequency in some tropical areas in Southeast Asia. However, it has also been estimated a runoff reduction between $10 \%$ and $30 \%$ in some dry regions of middle latitudes and in the dry tropics, due to the decrease in rainfall, Mexico is located in the latter case. Nevertheless, some years are expected to be above average with intense storm events, this happened in Mexico during 2010 until September. In summary, it will be difficult to have historical precipitation patterns and thus, successful water resources planning should take in account hydrological modifications imposed by global warming.

In addition, the IPCC has estimated with a high degree of confidence many semi-arid areas along the American continent will experience a decrease in water resources as a result of climate change. Drought effects will cover greater areas affecting multiple sectors, such as, agriculture, water supply and energy generation. Global warming will produce higher evapotranspiration rates in crops, thus a higher demand for irrigation will increase substantially, however water supplies in reservoirs and aquifers might be limited as well.

\subsection{Surface runoff estimation}

In Mexico, the official method to estimate surface runoff in basins is called 'NOM-011' [7]. Such method is required to be used when water balances are computed. In such method, the annual runoff volume $(\mathrm{V})$ in $^{3}$ is determined as follows: 
where:

$$
V=P \cdot A \cdot C_{e}
$$

P: annual precipitation ( $\mathrm{mm})$

A: basin area $\left(\mathrm{Km}^{2}\right)$

$\mathrm{C}_{\mathrm{e}}$ : runoff coefficient (dimensionless)

In order to estimate the runoff volumes due to climate change, in Equation (1) the variable to adjust is the annual precipitation $(\mathrm{P})$, which comes from 23 OAGCMs. Figure 1 shows this process schematically.

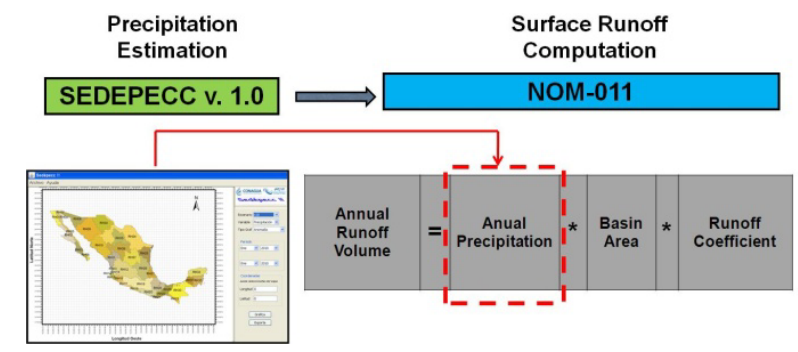

Figure 1: $\quad$ Precipitation estimation and surface runoff computation.

Runoff coefficient $\left(\mathrm{C}_{\mathrm{e}}\right)$ in Equation (1) depends on the type of soil and land use (were assumed constant in all climate change scenarios) and the annual precipitation (P). A nationwide soils map published by SEMARNAT was used [8]; this map represents a hydrologic classification of soils into four groups using the ISRIC (International Soil Reference and Information Centre) soil classification system. In terms of land use, the map published by CONABIO was employed [9]. This map groups the land use into 54 classes. Soil maps and land use cover maps were exported as raster maps with a spatial resolution of $100 \mathrm{~m}$. From both maps, a weighted value of the infiltration parameter $\mathrm{K}$ (dimensionless) was obtained and the annual runoff coefficient $\left(\mathrm{C}_{\mathrm{e}}\right)$ computed with Equations (2) and (3). Notice that infiltration parameter $\mathrm{K}$ was assumed constant in all time horizons; however, runoff coefficient $\left(\mathrm{C}_{\mathrm{e}}\right)$ differs in climate change scenarios.

$$
\begin{gathered}
\text { If } \mathrm{K} \leq 0.15: \quad C_{e}=\frac{K(P-250)}{2,000} \\
\text { If } \mathrm{K}>0.15: \quad C_{e}=\frac{K(P-250)}{2,000}+\frac{K-0.15}{1.50}
\end{gathered}
$$

\section{Global hydrologic vulnerability}

The IPCC [6] defines vulnerability as follows: "Vulnerability is the degree to which a system is susceptible to, and unable to cope with, adverse effects of climate change, including climate variability and extremes. Vulnerability is a function of the character, magnitude, and rate of climate change and variation to which a system is exposed, its sensitivity, and its adaptive capacity". Therefore, three factors were considered: exposure, sensitivity and adaptive capacity. 


\subsection{Degree of exposure}

Generally involves natural risks, such as hurricanes, floods, drought, landslides and sea level rise. In surface hydrology, it was interpreted as the change in surface runoff, which is directly related to precipitation. To identify the regions where the precipitation change will occur, Rivas [10] proposed the Precipitation Index of Climate Change ( $\left.\mathrm{PI}_{\mathrm{cc}}\right)$ :

$$
P I_{C C}=1-\frac{P_{C C}}{P_{H}}
$$

where:

$\mathrm{P}_{\mathrm{CC}}$ : Annual Precipitation due to climate change (mm)

$\mathrm{P}_{\mathrm{H}}$ : Historical Annual Precipitation (mm)

A value of 0 in the PI ${ }_{C C}$ would represent no precipitation change, while a value of 0.10 would indicate a $10 \%$ reduction in historical precipitation. The proposed index was computed in the four climate change scenarios shown in the Table 1. In a similar way, Rivas [10] came up with the following Surface Runoff Index to Climate Change (SRI $\mathrm{CC}_{\text {): }}$

$$
S R I_{C C}=1-\frac{S R V_{C C}}{S R V_{H}}
$$

where:

SRV $_{\mathrm{CC}}$ : Surface Runoff Volume due to climate change $\left(1 \times 10^{6} \mathrm{~m}^{3} /\right.$ year $)$ $\mathrm{SRV}_{\mathrm{H}}$ : Historical Surface Runoff Volume $\left(1 \times 10^{6} \mathrm{~m}^{3} /\right.$ year $)$

Surface runoff volumes in Equation (5) were determined with the Equation (1). The SRI $\mathrm{CC}_{\mathrm{CC}}$ represents the expected fraction in which the historical annual runoff will decrease. Historical records (until 2009) evaluate the initial condition and the evaluation of time horizons (2030 and 2050) from the AOGCMs results.

\subsection{Sensitivity}

This factor evaluates the degree of susceptibility to climate change, in other words how people will be affected. The factor was interpreted by the inhabitants living in each municipality based on a recent nation-wide survey [11].

\subsection{Adaptive capacity}

This factor refers to the potential to adapt to climate change, where two subfactors were considered: the groundwater aquifers and the poverty level in municipalities, quantified by the Social Margination Index [12]. Adaptive capacity represents the degree of resilience in the basin due to a decrease in surface runoff. 


\subsubsection{Exploitation level in aquifers}

National Water Commission (CONAGUA by its name in Spanish) classified the exploitation level in aquifers under two broad categories [13]: sub-exploited (where the rainfall natural recharge is greater than the extraction) and overexploited (where the opposite occurs). Population centers and irrigation areas located on top of over-exploited aquifers will have a higher vulnerability than those located on top of sub-exploited aquifers.

\subsubsection{Social margination index}

The Social Margination Index covers several socio-economic indicators [12]: illiteracy degree, completed primary education, sanitary services, electric power, access to water supply and income level, among others. Municipalities with a high margination index are more vulnerable to handle climate change effects due to the lack of a reliable source of clean water, for example.

\subsection{Calculation methodology}

In this study, vulnerability is a function of four variables: $\mathrm{SRI}_{\mathrm{CC}}$, population, exploitation level in aquifers and social margination index. Each variable was first normalized, then weighting factors were allocated and finally, the overall climate change vulnerability was computed. Notice that $\mathrm{SRI}_{\mathrm{CC}}$ did not need normalization. Sub-exploited and over-exploited aquifers were allocated values of 0 and 1 , respectively. Population and social magination indexes $\left(\mathrm{X}_{\mathrm{i}}\right)$ were normalized as follows:

where:

$$
Z_{i}=\frac{X_{i}-X_{i \_ \text {min }}}{X_{i \_ \text {max }}-X_{i \_ \text {min }}}
$$

$\mathrm{Z}_{\mathrm{i}}$ - Normalized Variable

$\mathrm{X}_{\mathrm{i}}$ - Non-normalized Variable

$X_{i, \min }$ - Minimum value of $X_{i}$

$\mathrm{X}_{\mathrm{i}, \max }$ - Maximum value of $\mathrm{X}_{\mathrm{i}}$

Since each variable has a different degree of importance, it was necessary to allocate to each one a weighting factor which denotes their importance in relation to the others. The allocation of specific weights $\left(\mathrm{W}_{\mathrm{i}}\right)$ was made based on an Analytic Hierarchy Process (AHP) developed by Saaty [14], which is a general mathematical procedure that compares the relative importance between pairs of variables and summarizes the results by assigning specific weights meeting the following condition:

$$
\sum_{i=1}^{n} W_{i}=1.0
$$

Such comparison was done with a field survey and a group of twenty experts from several disciplines related to water resources (managers, hydrologists, hydraulic engineers, sociologists and economists) were chosen to participate. Survey results were averaged using an Analytic Network Process (ANP) proposed by Adams [15] and the specific weights shown in Table 2 were 
Table 2: $\quad$ Variables that determine global hydrologic vulnerability.

\begin{tabular}{|c|c|c|c|c|}
\hline $\begin{array}{c}\text { IPCC } \\
\text { Component }\end{array}$ & Variable & $\begin{array}{c}\text { Normalized } \\
\text { Index }\end{array}$ & \multicolumn{2}{|c|}{ Weighting Factor } \\
\hline Exposure & Surface Runoff Index & SRI $_{\mathrm{CC}}$ & $\mathrm{W}_{\mathrm{S}}$ & 0.71 \\
\hline Sensitivity & Municipal Population & IPop & $\mathrm{W}_{\mathrm{P}}$ & 0.13 \\
\hline \multirow{2}{*}{$\begin{array}{c}\text { Adaptive } \\
\text { Capacity }\end{array}$} & Social Margination Index & IMarg & $\mathrm{W}_{\mathrm{M}}$ & 0.09 \\
\cline { 2 - 5 } & Exploitation levels in aquifers & IAquifer & $\mathrm{W}_{\mathrm{A}}$ & 0.07 \\
\hline
\end{tabular}

obtained. The overall hydrologic vulnerability to climate change was calculated by Equation (8) and the final step was to show the spatial results using GIS.

$$
\text { Vulnerability }=S R I_{C C} \cdot W_{S}+I \text { Pop } \cdot W_{P}+I M a r g \cdot W_{M}+I \text { Aquifer } \cdot W_{A}
$$

\section{Lerma-Chapala Basin}

\subsection{Location}

The proposed methodology was applied in the Lerma-Chapala Basin located in the central part of Mexico, which has an extension of $54,450 \mathrm{Km}^{2}$.

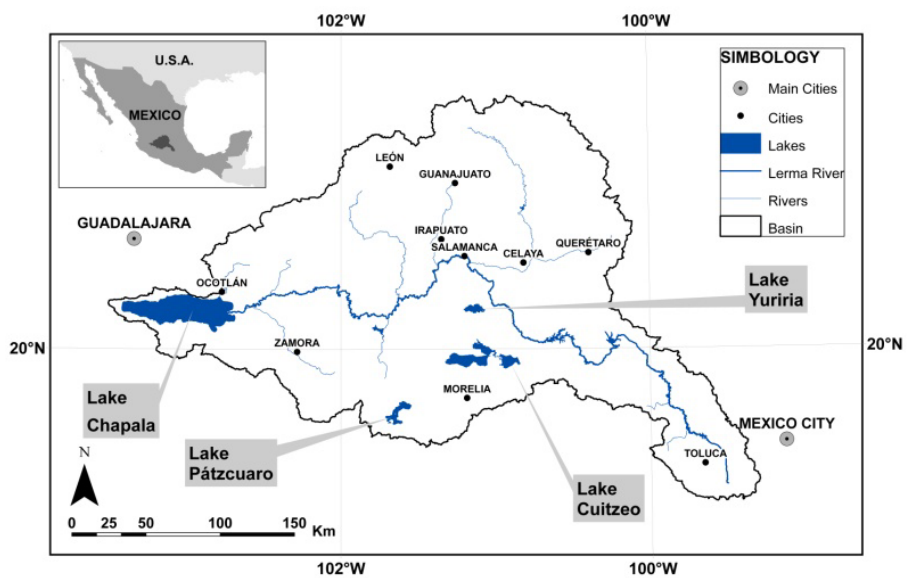

Figure 2: $\quad$ Lerma-Chapala Basin.

Lerma River is the main stream; it starts at 4,600 masl and ends in the Lake Chapala at 1,600 masl. Some important cities are located in the basin, $15 \%$ of Mexico's population live in this basin. Due to its location between the two largest cities in the country: Mexico City and Guadalajara, a great network of industrial and commercial activities has been developed. Given the explosive population growth during the last 40 years, it has been a significant environmental degradation whose rehabilitation represents a real challenge for the current generation. 


\subsection{Climate and hydrography}

The basin has an annual precipitation of $714 \mathrm{~mm}$, presenting extremes of $1,000 \mathrm{~mm}$ in the southeast and $400 \mathrm{~mm}$ in the north [5].

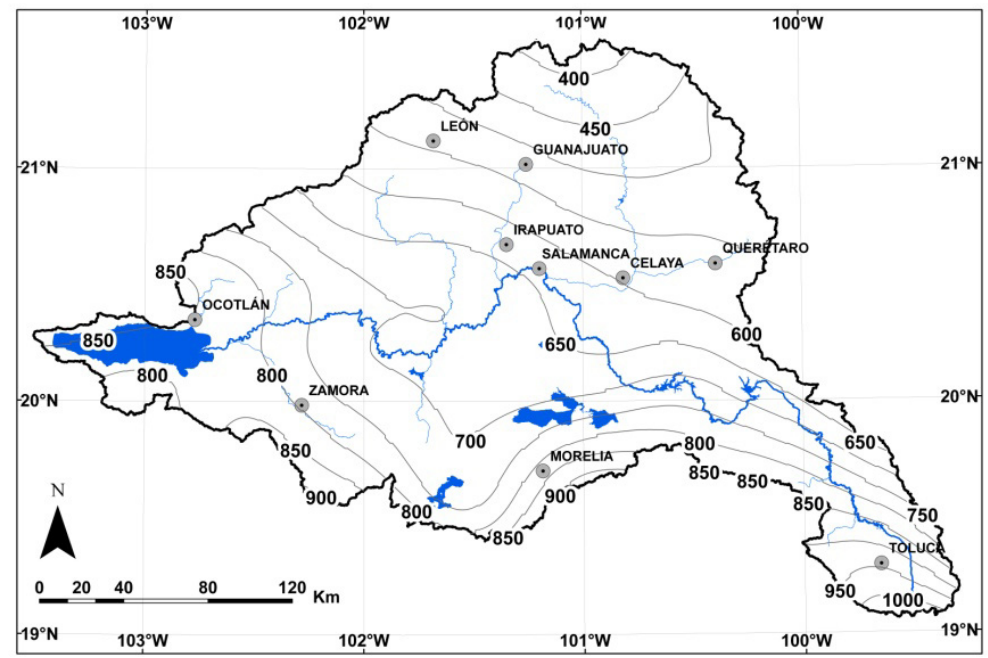

Figure 3: Average annual precipitation ( $\mathrm{mm})$.

Lerma River is approximately $750 \mathrm{Km}$ long and has some tributaries along its way, such as La Gavia, Jaltepec, La Laja, Silao-Guanajuato, Turbio, Angulo and Duero. During average conditions, surface runoff is completely used, either for irrigation or for water supply to urban centers or to meet industrial demands. The Lake Chapala has a length of $77 \mathrm{Km}$ and a width of $23 \mathrm{Km}$. Lake Chapala is the largest water body in Mexico and the third in Latin America. The maximum storage capacity is $8.13 \mathrm{Km}^{3}$, the surface area is approximately $110,000 \mathrm{ha}$, the average depth is $7.20 \mathrm{~m}$ and the maximum depth is $16 \mathrm{~m}$. The small amount of Lerma water entering the lake is highly polluted by untreated waste water from households, industrial sewage as well as fertilizers in form of nitrates and phosphates from agriculture. Lake Chapala is the most important supplier of drinking water for the city of Guadalajara. Illegal water withdrawals for agricultural and domestic purposes reduce the amount of water available.

\subsection{Hydrologic results}

The basin was divided in 14 sub-basins, whose average size was about $3,890 \mathrm{Km}^{2}$. The criterion of this subdivision was to evaluate the climate change effects in the major water bodies (lakes and dams). In each sub-basin, the annual precipitation and surface runoff were computed, considering historic conditions.

In both scenarios (A1B and A2), AOGCMs estimate that the average annual rainfall will decrease as we moving towards the end of the century, next Figure 4 
Table 3: $\quad$ Sub-basins in Lerma-Chapala Basin.

\begin{tabular}{|c|c|c|c|c|}
\hline \multirow{3}{*}{\multicolumn{2}{|c|}{ Basin }} & Drainage & Historic & Annual \\
\hline & & Area & Volume & Precipitation \\
\hline & & $\left(\mathrm{Km}^{2}\right)$ & $\left(\mathrm{Mm}^{3}\right)$ & $(\mathrm{mm})$ \\
\hline \multicolumn{2}{|r|}{ Total } & $54,450.0$ & 6,109 & 714.1 \\
\hline \multirow{14}{*}{ Sub-basins } & Lake Chapala & $6,306.2$ & 853 & 796.7 \\
\hline & Zula River & $2,125.4$ & 287 & 772.0 \\
\hline & Duero River & $2,802.9$ & 404 & 807.8 \\
\hline & Turbio River & $3,451.5$ & 298 & 587.3 \\
\hline & La Laja River & $6,868.5$ & 426 & 465.0 \\
\hline & Lerma Central & $8,884.7$ & 888 & 647.1 \\
\hline & Melchor Ocampo Dam & $2,046.9$ & 255 & 715.3 \\
\hline & Queretaro-Salamanca & $7,410.9$ & 662 & 595.9 \\
\hline & Solis Dam & $2,983.0$ & 386 & 737.9 \\
\hline & Tepuxtepec Dam & $3,488.9$ & 465 & 754.3 \\
\hline & Alzate Dam & $2,078.1$ & 383 & 913.3 \\
\hline & Lake Pátzcuaro $^{1}$ & 917.9 & 127 & 759.0 \\
\hline & Lake Cuitzeo $^{1}$ & $3,865.7$ & 538 & 776.8 \\
\hline & Lake Yuriria $^{1}$ & $1,219.4$ & 137 & 668.7 \\
\hline
\end{tabular}

${ }^{1}$ Closed basins (no surface runoff towards Lerma River).

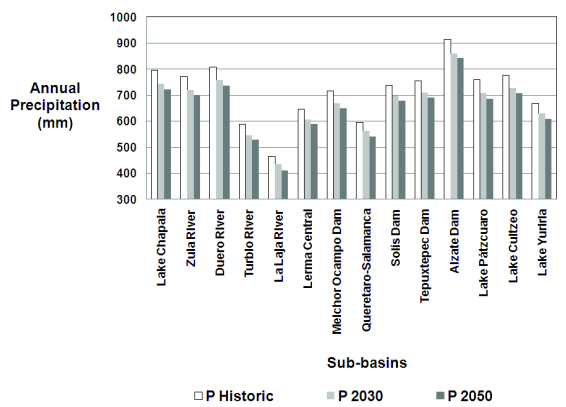

Figure 4: $\quad$ Precipitation effects (Scenarios A1B and A2).

shows the annual mean precipitation and the projected annual precipitation for the two scenarios. Scenario A2 showed higher precipitation decrements.

The corresponding $\mathrm{SRI}_{\mathrm{CC}}$ (Equations (1) and (5)) were calculated in each subbasin and shown in Figure 5. The north of the basin, presents maximum values of 0.21 (Scenario A2, year 2050).

\subsection{Hydrologic vulnerability}

North of the basin presented the highest vulnerability levels, where the cities of León and Guanajuato are located. In addition, most of the cities in this region (Leon, Guanajuato, Salamanca, Celaya and Querétaro) are located on top of overexploited aquifer [13]. 


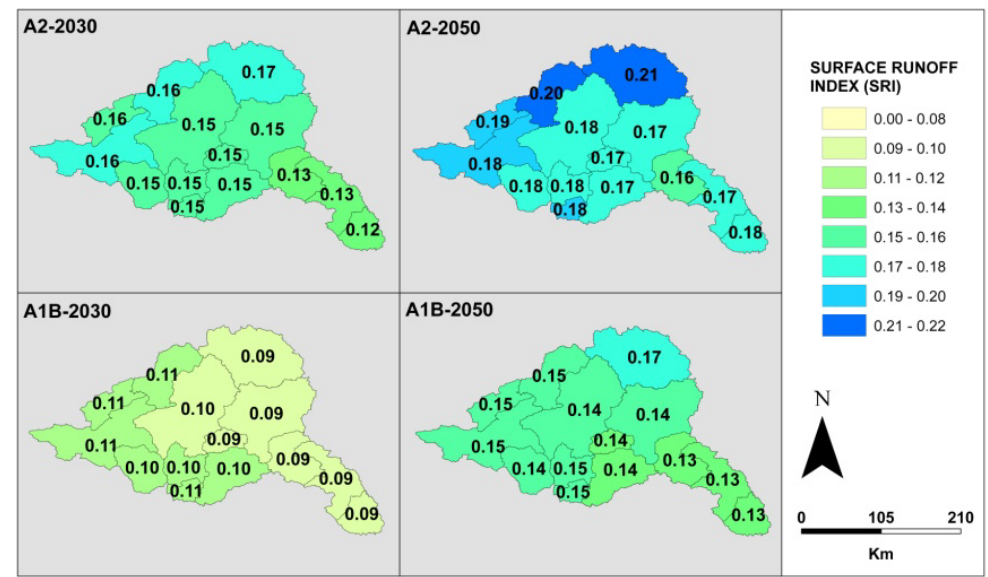

Figure 5: $\quad$ Surface runoff index (SRI).

In the most vulnerable region, the average annual precipitation of $550 \mathrm{~mm}$ is below the national average of $760 \mathrm{~mm}$, so the surface runoff is not enough to meet the intense domestic and industrial activities. Given the low precipitation and a lack of waste water treatment plants, streams are highly polluted by industrial discharges. In Leon, the footwear industry has been seriously impaired the water quality in rivers. As an adaption attempt, in April 2011 a new $122 \mathrm{Km}$ long aqueduct started to operate, the project included a diversion dam and a water treatment plant. The new infrastructure will provide $50 \mathrm{Mm}^{3}$ per year and it is expected to meet Queretaro's water demand for the next 30 years. The construction lasted three years and the inversion cost was USD 210 millions.

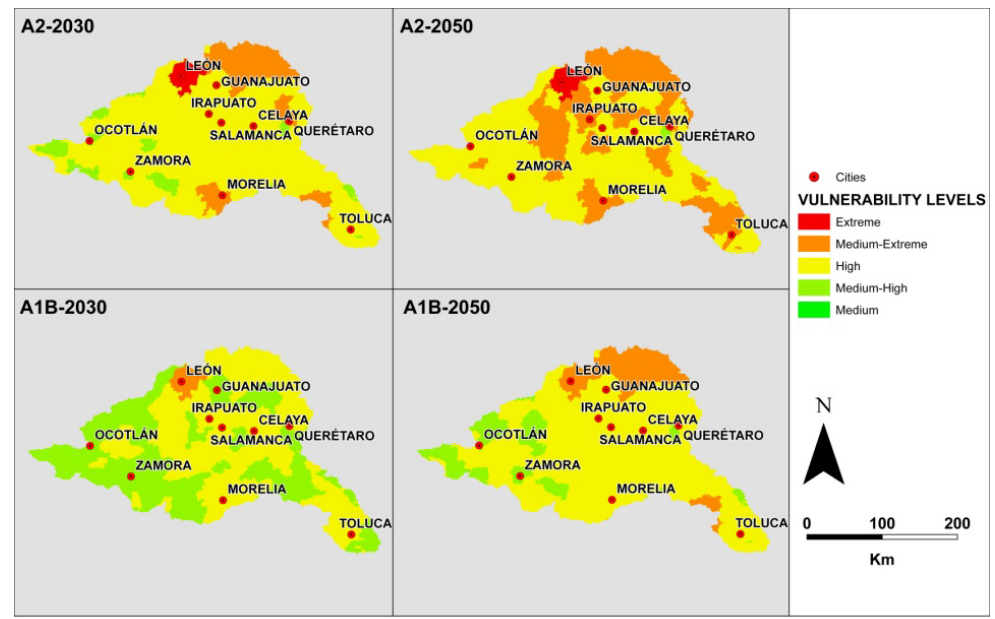

Figure 6: Hydrologic vulnerability. 


\section{Conclusions and recommendations}

This paper quantified the expected amount of surface runoff due to climate change in the Lerma-Chapala Basin, Mexico. This change was based upon the estimated precipitation from AOGCMs. The results show a clear tendency regarding modifications to the natural hydrological cycle, revealing expected decrements up to $21 \%$ in surface runoff (Scenario A2-2050) in the upper part of the Basin. From the vulnerability definition stated by the IPCC, a proposal for mapping vulnerability was suggested. The location of the most vulnerable regions was needed in order to identify where the adaptation efforts should be focused. As the case study showed, costly adaptation solutions could be implemented and solve the water scarcity issues for some years, however, the environmental sustainability of the adjacent basin is being threatened. Therefore, always local adaptation projects should be considered first and preferred over massive civil engineering works.

Natural population growth was not included in this analysis; however, since natural runoff volumes are expected to decrease, water availability per capita is expected to decrease as well, which might cause a severe competition among water sectors, thus, efficient water use in population centers and irrigation zones must be enforced. At the outlet of the Basin, one of the main concerns is the Lake Chapala water levels. During 2001 and 2002 water levels reached critical low elevations. Since then, the Lake has experienced a recovery; in fact, in 2010 water levels remained high. However, based upon model results and the expected competence among water users, Lake Chapala could have a reduction in volume and the corresponding water quality issues may arise.

\section{References}

[1] Secretaria del Medio Ambiente y Recursos Naturales, SEMARNAT (2009). Programa Especial de Cambio Climático 2009-2012. Diario Oficial de la Federación. Viernes 28 de agosto de 2009.

[2] SEMARNAT (2010). Cambio Climático en Mexico. http://cambio_ climatico.ine.gob.mx/ (June 21, 2010)

[3] IPCC, Intergovernmental Panel on Climate Change (2001). Climate Change 2001: The Scientific Basis. Contribution of Working Group I to the Third Assessment Report of the Intergovernmental Panel on Climate Change [Houghton, J.T.,Y. Ding, D.J. Griggs, M. Noguer, P.J. van der Linden, X. Dai, K. Maskell, and C.A. Johnson (eds.)]. Cambridge University Press, Cambridge, United Kingdom and New York, NY, USA.

[4] IPCC, Intergovernmental Panel on Climate Change (2007). Climate Change 2007: The Physical Science Basis. Contribution of Working Group I to the Fourth Assessment Report of the Intergovernmental Panel on Climate Change [Solomon, S., D. Qin, M. Manning, Z. Chen, M. Marquis, K.B. Avery, M. Tignor and H.L. Miller (eds.)]. Cambridge University Press, Cambridge, United Kingdom and New York, NY, USA. 
[5] Instituto Mexicano de Tecnología del Agua, IMTA (2009). Subcooordinación de Hidrometeorología. Sistema para la Exhibición de Datos del Ensamble Ponderado de Escenarios de Cambio Climático para México (SEDEPECC, v 1.0).

[6] IPCC, Intergovernmental Panel on Climate Change (2007). Summary for Policymakers. The Physical Science Basis. Contribution of Working Group I to the Fourth Assessment Report of the Intergovernmental Panel on Climate Change [Solomon, S., D. Qin, M. Manning, Z. Chen, M. Marquis, K.B. Avery, M. Tignor and H.L. Miller (editors)]. Cambridge University Press, Cambridge, United Kingdom and New York, NY, USA.

[7] Comisión Nacional del Agua, CNA (2000). Norma Oficial Mexicana NOM-011-CNA-2000. México, D.F.

[8] SEMARNAP, Subsecretaría de Recursos Naturales (1998). "Mapa de suelos dominantes de la República Mexicana". (Primera aproximación 1996). Escala 1:4’000,000. México.

[9] CONABIO, Comisión Nacional para el Conocimiento y Uso de la Biodiversidad (1988). "Uso de suelo y vegetación de INEGI agrupado por CONABIO”. Escala 1:1'000,000. Modificado de: Instituto Nacional de Estadística, Geografía e Informática (INEGI) - Instituto Nacional de Ecología (INE), (1996). Uso del suelo y vegetación, escala 1:1’000,000. México.

[10] Rivas, I. (2009). Secretaria del Medio Ambiente y Recursos Naturales, SEMARNAT. Instituto Mexicano de Tecnología del Agua. Atlas de Vulnerabilidad Hídrica en México ante el Cambio Climático: Aguas Superficiales.

[11] Instituto Nacional de Estadística Geografía e Informática, INEGI (2005). II Conteo de Población y Vivienda 2005. México y sus municipios.

[12] Consejo Nacional de Población, CONAPO (2005). Índices de marginación, 2005. Primera edición: Noviembre de 2006. México, D. F. http://www.conapo.gob.mx (Abril 30, 2010)

[13] Secretaria del Medio Ambiente y Recursos Naturales, SEMARNAT (2009). Atlas del Agua en México, Comisión Nacional del Agua. México, D.F.

[14] Saaty, T. (2001). The Analytic Network Process: Decision Making with Dependence and Feedback. RWS Publications, 4922 Ellsworth Avenue, Pittsburgh, PA 15213.

[15] Adams, B. (2010). Super Decisions software. Creative Decisions Foundation. 4922 Ellsworth Avenue, Pittsburgh, PA 15213, USA. http://www.superdecisions.com/ 